\title{
Complete Combustion Control for a Steam Boiler Plant
}

\author{
A. Darwish, I. Morsi, and A. El Zawawi
}

\begin{abstract}
Steam boiler is one of the most widely used industrial systems. The boiler is used in many industrial applications. It produces steam and is used for many purposes, for example as a heat exchanger used in the refining and separation of oil and is used in electricity production also. Like any combustion system, boilers burn fossil fuels to generate steam. Emissions from fuel include carbon monoxide and nitrogen oxides. Incomplete combustion increases these emissions. The way to reduce these emissions is the control of combustion to make complete combustion by monitoring exhaust components like (NOx, $\mathrm{CO2}$, $\mathrm{CO}$ and O2). Steam boilers are usually controlled for steam pressure only without including the exhaust components in the control loop. In this paper, a limiter for exhaust components will be included in the control loop beside the steam pressure control. This paper outlines the various stages of operation involved in the conversion of a manually operated boiler towards a fully automated one. Over the years, the demand for high quality, greater efficiency and automated machines has increased. The first part of the paper focuses on passing the inputs to the boiler at a required temperature, so as to constantly maintain a particular temperature in the boiler. The air preheater and economizer help in this process. The paper mainly focuses on level, pressure and flow control at the various stages of the boiler plant. The temperature in the boiler is constantly monitored. The automation is further enhanced by constant monitoring using a Supervisory Control and Data Acquisition system (SCADA) screen which is connected to the PLC by means of a communication cable. This paper describes the construction of SCADA and the corresponding Human Machine Interface (HMI) for a steam boiler plant. This last consists of the water drum, the air heaters and the main boiler. The control system of the plant is implemented using Siemens SIMATIC S7 PLC with ladder programming and WINCC to create the SCADA/ HMI system.
\end{abstract}

Index Terms - Boiler, PLC, SCADA.

\section{INTRODUCTION}

L ATELY Egypt has been trying to expand in the industrial field, especially in the sectors of electricity generation, oil refining, and petrochemicals production [1]. Over the years, the demand for high quality, greater efficiency, and automated machines has increased in the industrial sector.

Ahmed Darwish, is with Department of Electronics and Communication Engineering Arab Academy for Science and Technology, Alexandria, Egypt, (e-mail: fairejeune@gmail.com).

Iman Morsi, is with Department of Electronics and Communication Engineering Arab Academy for Science and Technology, Alexandria, Egypt, (e-mail: drimanmorsi@yahoo.com).

Amr El Zawawi, is with Department of Electrical Engineering University of Alexandria, Alexandria, Egypt, (e-mail: amr.elzawawi@yahoo.com).
Huge plants require continuous monitoring and inspection at frequent intervals. There are possibilities of errors at measuring and at various stages involved with human workers and the lack of few features of microcontrollers [2]. SCADA and the corresponding HMI are used in many large and medium systems. The SCADA development programs are proprietary and PLC dependent [3, 4].

The steam boiler plant is a large application which needs a large PLC. S7 300 is chosen to operate the plant which consists of a water drum, feed water pumps, air heater and condenser.

A boiler is defined as a closed vessel in which steam is produced from water by the combustion of fuel. Generally, in boilers steam is produced by the interaction of hot flue gases which is coming out from the fuel, mainly coal or coke, with water pipes. In boilers, the chemical energy of stored fuel is converted into heat energy which is absorbed of water that converts it to steam. Due to poor understand of working principles boilers have many serious flaws. Low water level may overheat boiler tubes and damage them. Various controlling mechanism are used to control the boiler system so that it works properly [5].

\section{INSTRUMENTATION}

To detect the level of different parameters several samples have been taken from Alexandria Petroleum Company from January 2014 to June 2014 and the new boiler at Middle East Oil Refinery MEDOR with new CEMS (Continuous Emission Monitoring System) from September 2014 to March 2015.

\section{A. Oxygen Measurement}

Yokogawa Model ZR22G separate type zirconia oxygen analyzer is used to measure the quantity of oxygen in the boiler exhaust. A solid electrolyte such as zirconia measures the conductivity of oxygen ions at high temperatures. Therefore, a zirconia-plated element with platinum electrodes on both sides is heated up in contact with gases having different oxygen partial pressures on each side is stable as a concentration cell. As the gas comes in contact with the zirconia element in the negative electrode, oxygen molecules in the gas acquire electrons and become ions. Moving in the zirconia element, electrons arrive at the positive electrode on the opposite side. There, the electrons are released and the ions return to the oxygen molecules. This reaction is indicated as follows [6]:

$$
\text { Negative electrode: } \mathrm{O}_{2}+4 \mathrm{e} \rightarrow 2 \mathrm{O}_{2}^{-}
$$


Positive electrode: $2 \mathrm{O}_{2}^{-} \rightarrow \mathrm{O}_{2}+4 \mathrm{e}$

The induced voltage $\mathrm{E}(\mathrm{mV})$ between the two electrodes, generated by the reaction, is governed by Nernst's equation as follows:

$$
\mathrm{E}=-(\mathrm{RT} / \mathrm{nF}) \ln (\mathrm{Px} / \mathrm{Pa})
$$

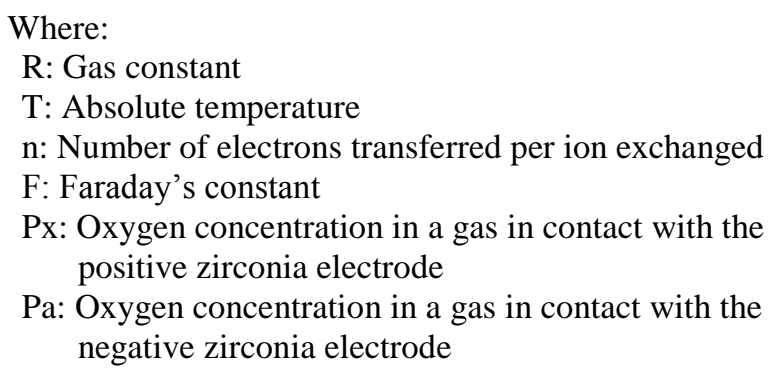

\section{B. CO Analyzer}

Teledyne API Model 300 CO Analyzer measures low ranges of carbon monoxide by comparing infrared energy absorbed by a sample to that absorbed by a reference gas. This is accomplished by a Gas Filter wheel, which alternately allows a high energy light source to pass through a CO-filled chamber and a chamber with no $\mathrm{CO}$ present. The light path then travels through the sample cell, which has a folded optical path of 14 meters. The energy loss through the sample cell is compared with the zero reference signal provided by the gas filter to produce a signal proportional to concentration, with little effect from interfering gases within the sample. This design produces excellent zero and span stability and a high signal-to-noise ratio allowing extreme sensitivity [7].

\section{Oxides of Nitrogen}

Emerson Model 951C which uses chemiluminescence detection technique, is based on the principle that nitric oxide $(\mathrm{NO})$ reacts with ozone $(\mathrm{O} 3)$ to produce nitrogen dioxide (NO2), $10 \%$ electronically excited nitrogen dioxide $\left(\mathrm{NO}_{2} *\right)$ and oxygen. Following the NO-O3 reaction, the NO2 molecules immediately revert to NO2. This process creates a light emission directly propor $\neg$ tional to the NO concentration in the sample. The intensity of the resulting light emission is then measured by a pho $\neg$ tomultiplier tube and associated electronics. An NO2 to NO converter is used for NOX (NO $+\mathrm{NO} 2)$ analysis [8].

$$
\begin{aligned}
& \mathrm{NO}+\mathrm{O}_{2} \rightarrow \mathrm{No} 2 *+\mathrm{O}_{2} \\
& \mathrm{No}_{2} * \rightarrow \mathrm{NO}+\mathrm{hr}
\end{aligned}
$$

\section{Pressure Measurement}

A common electrical pressure sensor design works on the principle of differential capacitance. In this design, the sensing element is a taut metal diaphragm located equidistantly between two stationary metal surfaces, comprising three plates for a complementary pair of capacitors. As shown in figure (1) an electrically insulating fill fluid transfers motion from the isolating diaphragms to the sensing diaphragm, and acts as an effective dielectric for the two capacitors [9].

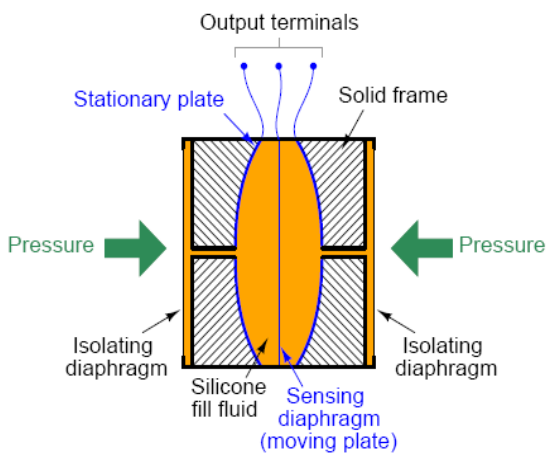

Fig.1. Differential capacitance sensors [9]

\section{E. Temperature Measurement}

Thermocouples generate their own electric potential. In some ways, this makes thermocouple systems simpler because the device receiving the thermocouple signal does not have to supply electric power to the it. Thermocouples exist in many different types, each with its own color codes for the dissimilarmetal wires. Type (E) can measure from $0{ }^{\circ} \mathrm{C}$ to $1000{ }^{\circ} \mathrm{C}$. It is suitable to use in this process [9].

\section{F. Level Measurement}

Ultrasonic level instruments measure the distance from the transmitter to the surface of a process material located farther below using reflected sound waves. The frequency of these waves extends beyond the range of human hearing. This is why they are called ultrasonic. The time of flight for a sound pulse indicates this distance, and is interpreted by the transmitter electronics as process level. These transmitters may output a signal corresponding either to the fullness of the vessel (fillage) or the amount of empty space remaining at the top of a vessel (ullage) and the actual level can be calculated as shown in the figure (2).

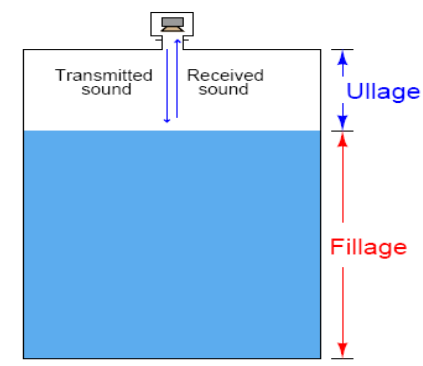

Fig.2. Ultrasonic level measurement [9]

\section{PRINCIPLE OF COMBUSTION}

To attain a clear understanding of the combustion control methods, a simple fuel like methane (CH4) is used. The chemical equation for the reaction of methane with oxygen is presented below. Methane will react with oxygen to release energy and form carbon dioxide as well as water. Each molecule of fuel would find the exact amount of oxygen to cause complete combustion. In case of methane, one molecule 
of methane must find two molecules of oxygen to produce a complete reaction [10].

$$
\mathrm{CH}_{4}+2 \mathrm{O}_{2} \rightarrow \mathrm{CO} 2+2 \mathrm{H}_{2} \mathrm{O}
$$

The combustion process does not proceed in a perfect manner. A fuel molecule may encounter less oxygen than is required for complete combustion. The result will be partial combustion. The exhaust gases will then contain some un-reacted fuel and some partially reacted fuel. Generally, these unburned fuel components are in the form of carbon monoxide (CO), hydrogen $(\mathrm{H} 2)$, and other fuel components that may include the fully un-reacted fuel source, which is methane (CH4) in this case [10].

$$
\mathrm{CH}_{4}+2 \mathrm{O}_{2} \rightarrow \alpha \mathrm{CO}_{2}+\beta \mathrm{H}_{2} \mathrm{O}+\gamma \mathrm{CO}+{ }_{+} \mathrm{H}_{2}+\varepsilon \mathrm{CH}_{4}+\zeta \mathrm{O}_{2}
$$

Unburned fuel presents negative safety, health, environmental, and economic impacts on the boiler operation. As a result, it is imperative to manage the combustion process to maintain these components to minimum levels. So combustion management requires that extra oxygen be provided to the combustion zone to ensure all the fuel is reacted. But, the amount of extra oxygen must be minimized to reduce energy loss.

The measurements required to manage the combustion loss are the flue gas oxygen content and the flue gas combustible concentration. The flue gas oxygen content is measured to allow the combustion air flow to be controlled to meet a set point. Combustibles concentrations are measured to identify the minimum practical oxygen concentration.

There are many measurements required to obtain a boiler tuning. There are several critical measurements required to ensure good combustion. The critical measurements are oxygen concentration and flue gas combustibles concentration [11].

\section{SCADA SYSTEM}

SCADA is an acronym for Supervisory Control and Data Acquisition. SCADA systems are used to monitor and control a plant or equipment in industries such as water and waste control, energy, oil and gas refining and transportation. These systems encompass the transfer of data between a SCADA central host computer and Programmable Logic Controllers (PLCs), and the operator terminals [12].

A SCADA system gathers information, transfers the information back to a central site, then alerts the home station if anything occurred. These systems can be relatively simple, such as one that monitors environmental conditions of a small office building, or very complex, such as a system that monitors all the activities in a nuclear power plant or the activity of a municipal water system.

Many systems are monitored using the infrastructure of the corporate Local Area Network (LAN)/Wide Area Network (WAN). Wireless technologies are now being widely deployed for purposes of monitoring. WinCC is a powerful HMI system for use under Windows XP or Windows 7 to simulate a steam boiler plant. HMI stands for "Human Machine Interface", i.e. the interface between the human (the operator) and the machine (the process) [13].

\section{STEAm BoILER SYSTEM DESCRIPTION}

Steam required for the plants needs to be dry and at high temperature. Feed water coming to the economizer is evenly distributed in the drum by the feed water distribution pipe. Boiler water leaves the drum through the down comers to the water wall. The steam/water mixture coming from the water wall enters the drum in the primary steam separator, where water and steam are separated. Steam leaves the drum via the saturated steam line.

The drum contains a hold-up volume of water to produce steam for at least three minutes during failure of feed water supply. The drum is able to contain the swell of water volume of the water wall during start-up, when the start level is taken into account [14].

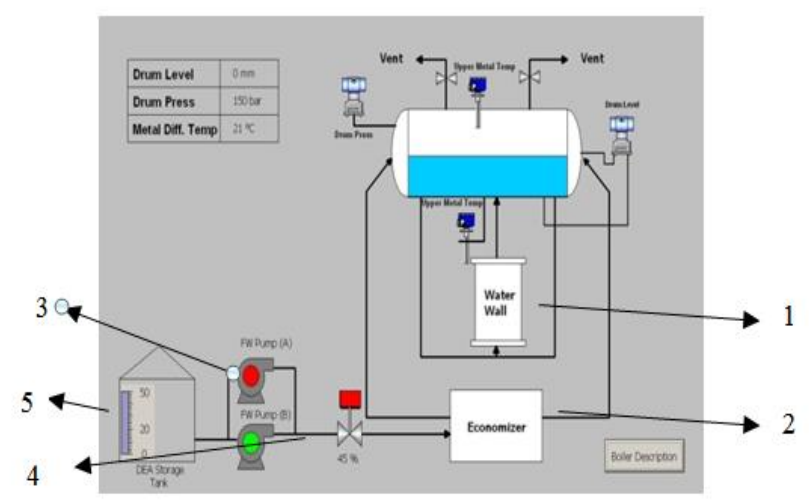

Fig.3. The Graphical User Interface (GUI) of the drum

Where:

1. Water wall

2. Economizer

3. Feed water pumps

4. Feed water valve

5. Dearator storage tank

\section{Steam BoIler Main Components}

Actually, a small amount of excess air is needed to ensure complete combustion. Air enters the furnace at different locations depending on the size. Boilers are usually equipped with chimneys to produce the draft necessary to move combustion air into the furnace and to discharge the combustion products, or flue gas to atmosphere. The draft must be produced high enough to provide enough air to burn the fuel without causing it to smoke and move the flue gas up to the chimney. Large boilers that use heat recovery equipment and air pollution control devices must use fans to move air through the system as shown in the figure (4) below; because of high draft losses produced by this add on equipment [15]. 


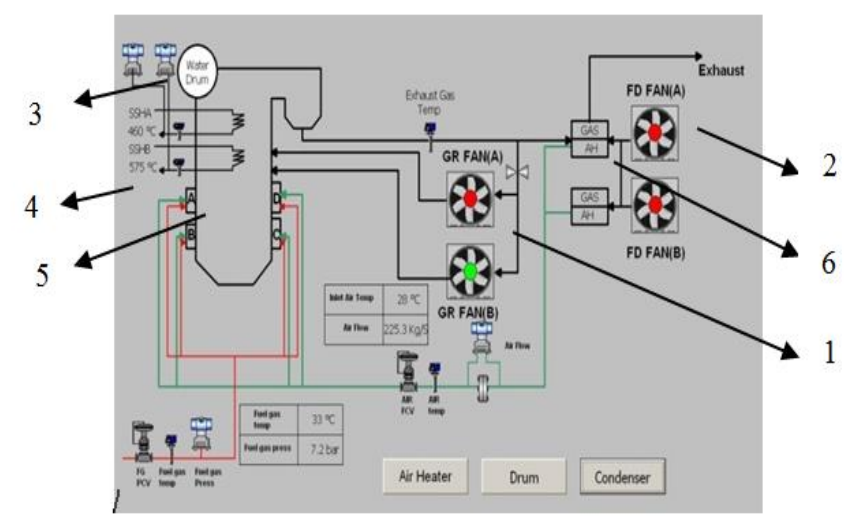

Fig.4. The Graphical User Interface (GUI) of the boiler

Where:

1. Gas Recirculation (GR) fans

2. Forced Draft (FD) fans

3. Water drum

4. Super heat coils

5. Main boiler

6. Air heater

\section{A. Air Heater}

Boilers are provided with air pre-heaters to recover heat from the flue gases. An increase of about $12 \%$ in boiler efficiency is achieved by providing air pre-heaters. Air pre-heaters are provided in boilers to preheat the combustion air before supplying it to the boiler as shown in the figure (5).

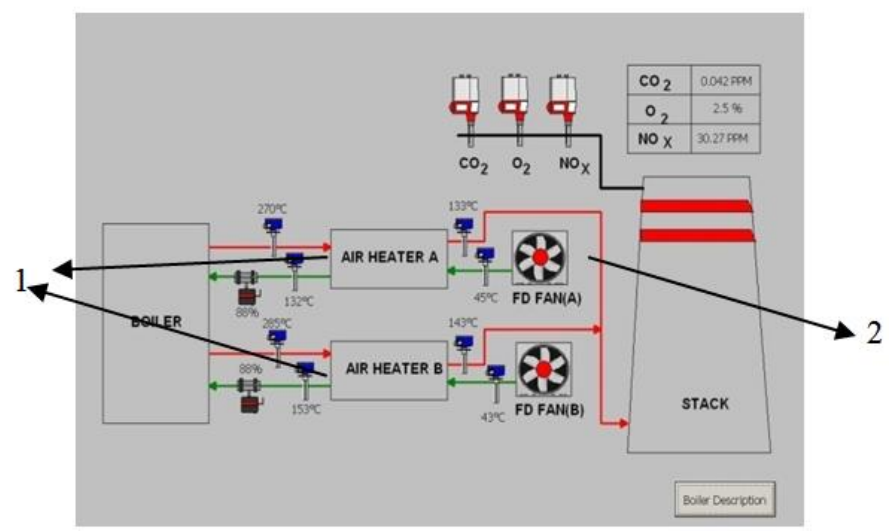

Fig.5. The graphical user interface of the air heaters

Where:

1. Air heaters

2. FD fans

\section{B. Steam Condenser}

The object of the condensate system is to condense the steam and circulate the water back to the drum. Steam is condensed in the condenser. The condensate is then pumped to the condensate preheater. In the preheater, the condensate is heated with heat from the returned stream. Part of the water from the preheater outlet is recirculated to the condensate preheater inlet as shown in the figure (6). This way, the minimum inlet temperature of the preheater is controlled above the water dew point of the flue gas. From the preheater, the condensate is directed to the deaerator.

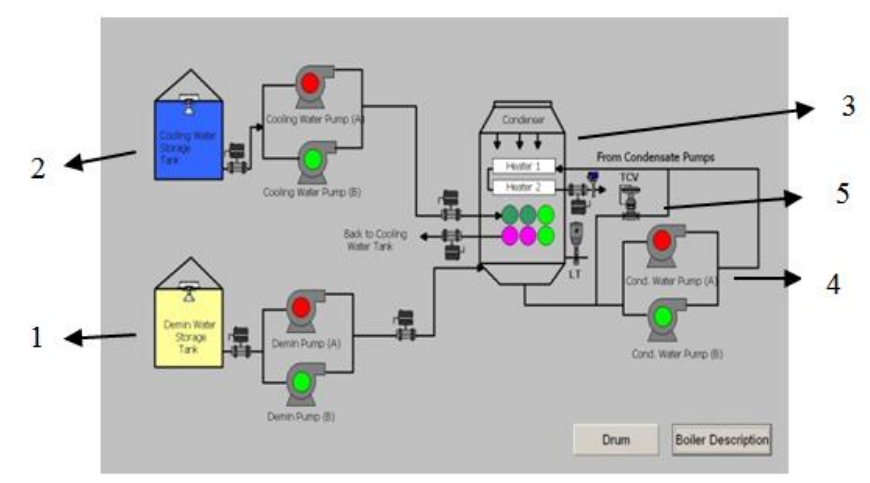

Fig.6. The Graphical User Interface (GUI) for the Condenser

Where:

1. Demineralised water storage tank

2. Cooling water storage tank

3. Condenser

4. Condensate water pumps

5. Condensate water temperature control valve

\section{RESULT}

The steam boiler plant, with a SCADA system is designed as well as the interface of this SCADA with the PLC . The HMI is programmed to interface with the field to achieve the different control tasks. Therefore at anytime, the valve can be opened or closed, and any pump can be started or stopped using the HMI according to the operation instructions. Face plates are used to open and close fans as shown in figure (7).

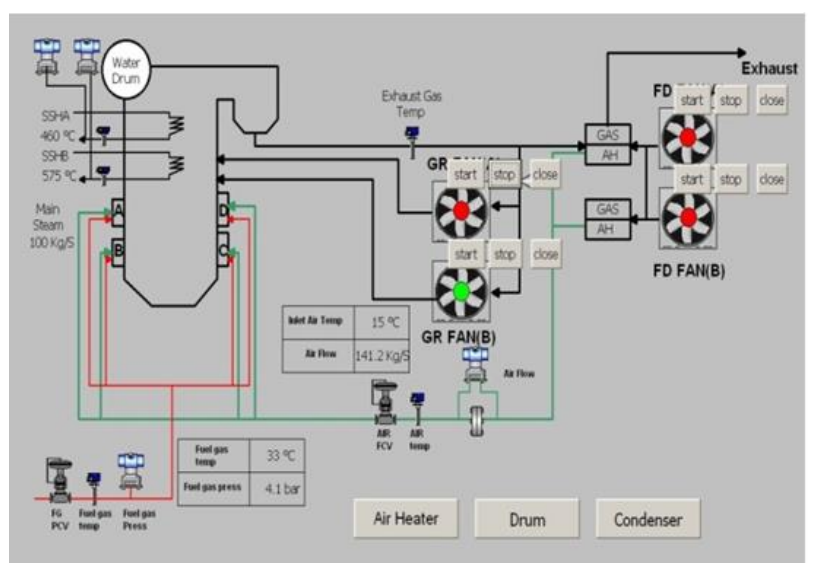

Fig.7. GUI of the boiler showing starts and stops for all fans

The combustion process should proceed in a perfect manner. A fuel molecule needs a limited quantity of air for complete combustion. In figures (8) and (9) fuel to air ratio changes as steam flow changes. 


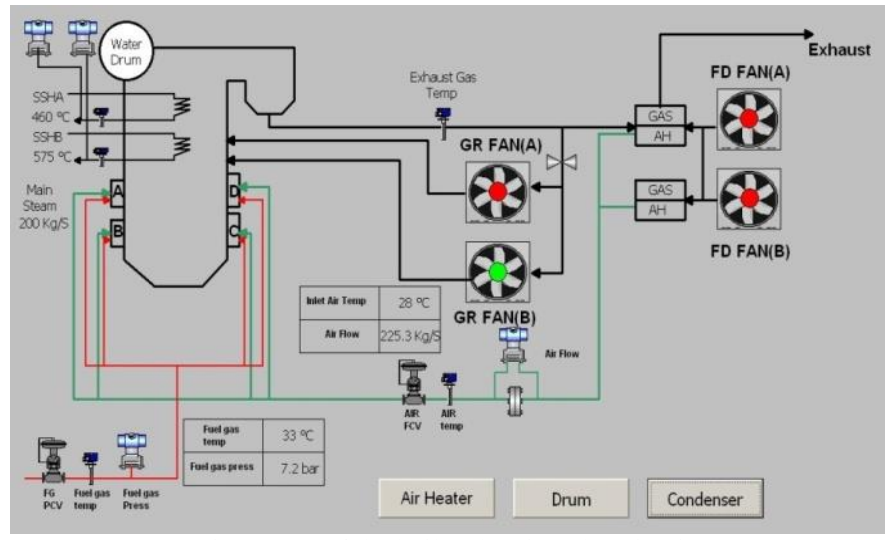

Fig.8. GUI of the boiler showing changing in the fuel to air ratio as steam flow changes

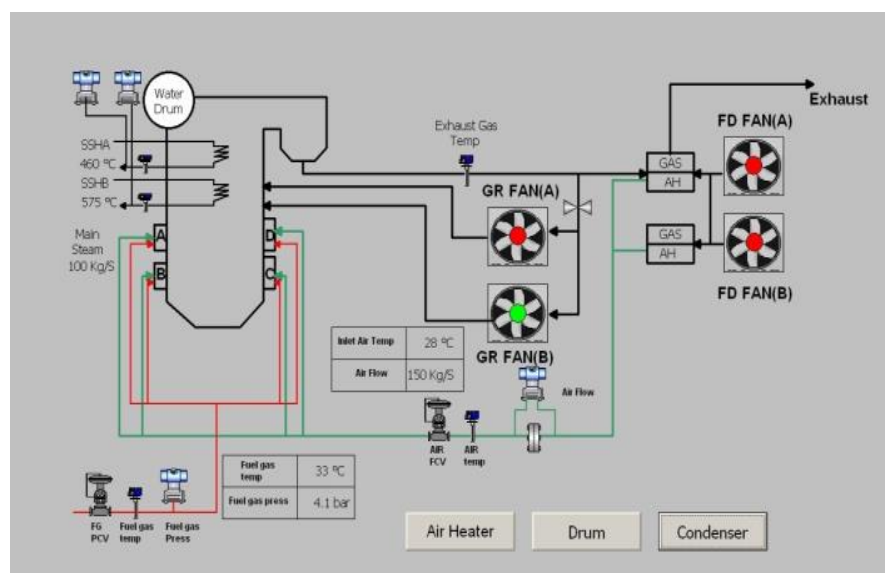

Fig.9. The GUI of the boiler showing fuel to air ratio at half load

At same steam flow demand, if combustion parameters change, like air temperature, it will lead to change the air density and fuel to air ratio. To avoid this case, the air flow control valve will change his value to compensate changing in fuel to air ratio as shown in figure (10). The air flow will be $141.2 \mathrm{~kg} / \mathrm{s}$.

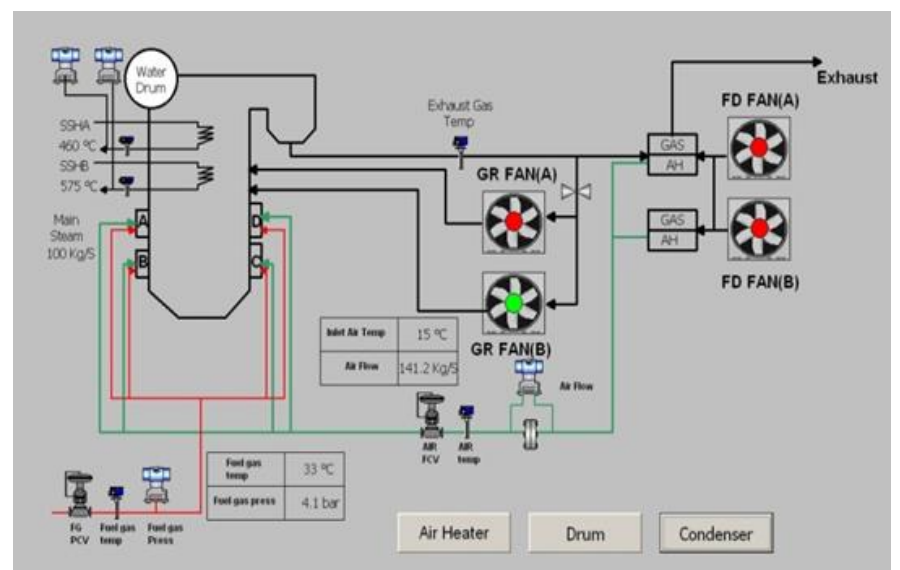

Fig. 10The Graphical User Interface (GUI) boiler showing changing in air flow as air temperature changes

Any large boiler burns a huge amount of fuel. Operating a plant without measuring its performance it will lead to decreasing its efficiency. By using Yokogawa Model ZR22G, described before, oxygen concentration can be detected as show in the figure (11).

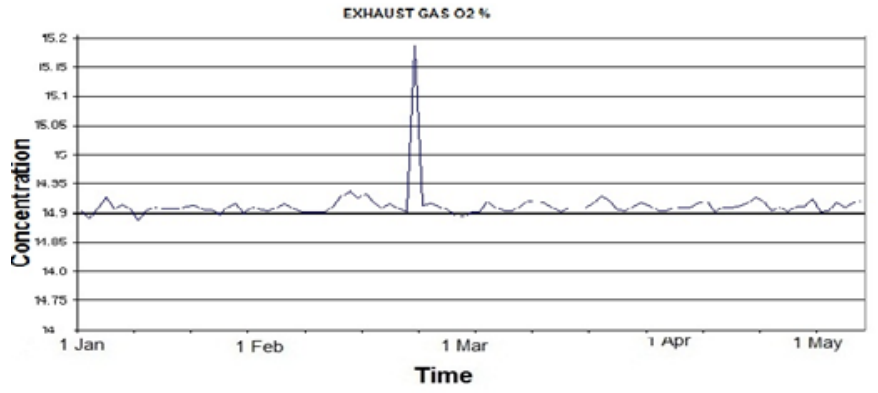

Fig.11. Oxygen concentration \%

By using CO analyzer, Model 6300E CO concentration can be detected as shown in figure (12).

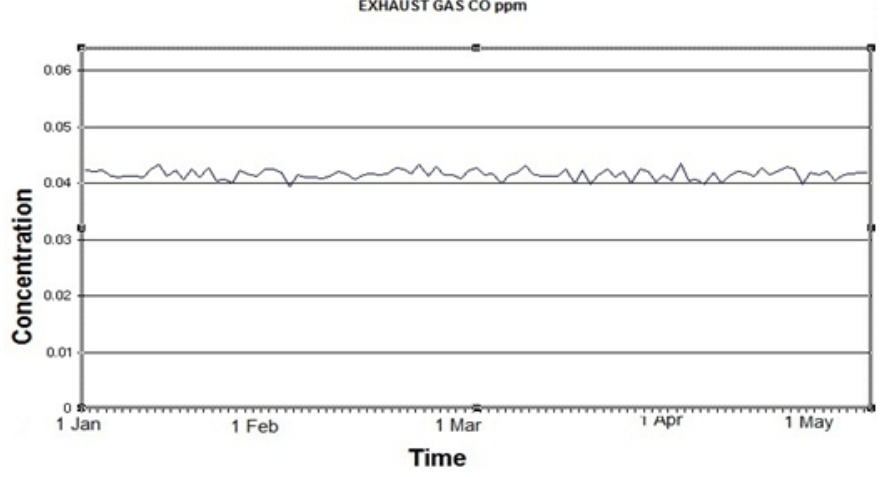

Fig.12. CO concentration (ppm)

By using Emerson Model 951C, NO concentration can be detected as shown in figure (13).

EXHAUST GAS NOX $\mathrm{ppm}$

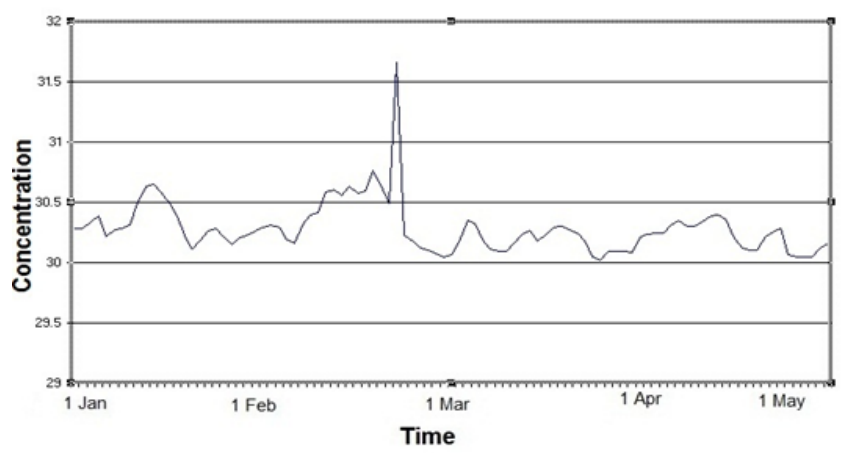

Fig.13. NO concentration (ppm)

Figure (14) shows the ambient temperature during 36 hours of continuous measurement using type $(\mathrm{E})$ thermocouple.

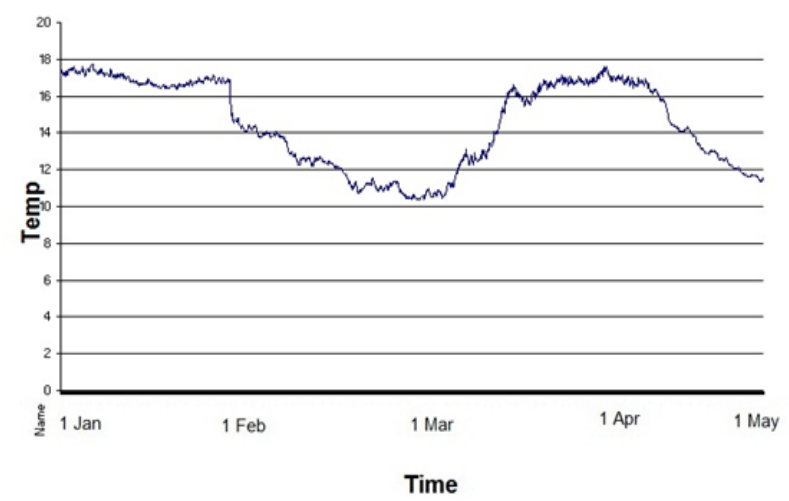

Fig.14. Inlet air temperature 
Figure (15) shows degradation of demineralized water level during 36 hours of continuous measurement showing maximum level and minimum levels. Demin Water Tank

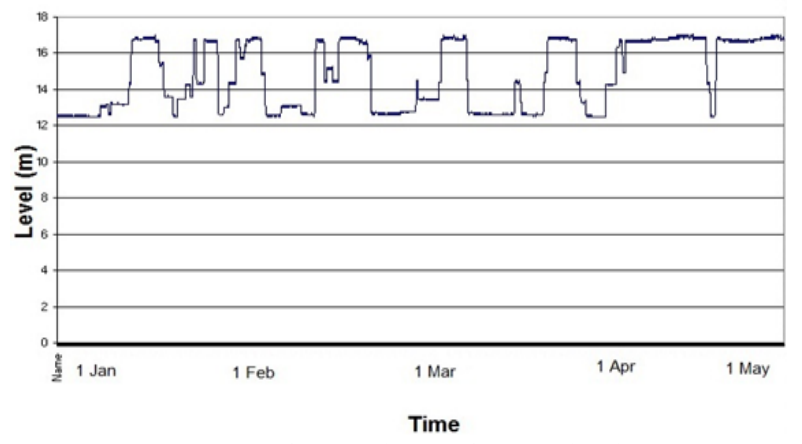

Fig.15. Inlet Demin water level

Any automatic control system should have instrument air to operate pneumatic valves. Its pressure should be within range as shown in figure (16).

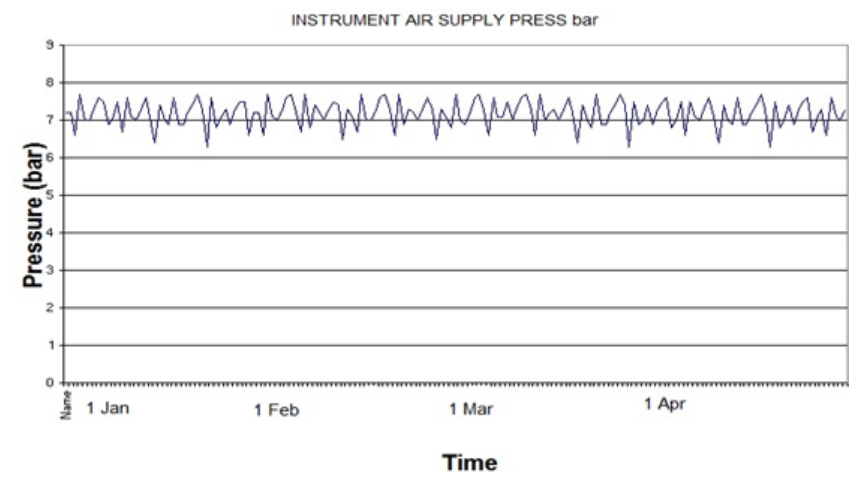

Fig.16. Instrument air pressure (bar)

\section{CONClusions}

An important aspect of any power plant is the boiler control. Several techniques can be implemented, but the used method relies on many objectives like: superior quality, increased efficiency, and high profit. SCADA system is used to collect data from the steam boiler plant and control it by sending and receiving control signals from and to this system $[16,17]$. In this system, WinCC is used to create graphics that is used to interface the operator to all the demineralization plant equipment. The most important benefits from using a SCADA system is decreasing man power and operating time by allowing the operator to control all equipment, take all instruments readings continually, allowing designing control functions, operate all equipment and store plant historical data to create graphic trends which allow the operator to monitor any change in the measured values and to allow more efficient operation. The advantage of using SCADA/PLC system is that the scan time needed to monitor the system, detect the problems, and executing the actions swiftly.

\section{REFERENCES}

[1] I. Morsi, A. El Zawawi and M. Amin, "Statistical Analysis Techniques for High Quality Water", Global Climat Change Conference, Alexandria, Egypt, 2013.
[2] I. Morsi, M. El Deeb, and A. El Zawawi, "SCADA/HMI Development for a Multi Stage Desalination Plant", Computation World Future Computing, Athens, Greece, pp. 67-71, 2009.

[3] K. Barnes and B. Johnson; "Introduction to SCADA Protection and Vulnerabilities", IEEE Transactions on Instrumentation and Measurement, Vol. 56, No. 1, February 2007. Electromagnetic Fields (300 Hz to $300 \mathrm{GHz}$ ), Environmental Health Criteria 137, World Health Organization, Geneva, Switzerland, 1993.

[4] Iman Morsi, Loay Mohy El-Din,"SCADA System for Oil Refinery Control", Elsevier Measurement Journal, Vol.47, 2014.

[5] K. Gowri Shankar, "Control of Boiler Operation using PLC - SCADA", International MultiConference of Engineers and Computer Scientists 2008 Vol II, Hong Kong.

[6] Yokogawa Zirconia Oxygen Analyzer, Model ZR22G, Datasheet, 8th Edition, 2012

[7] Teledyne API Model 300 CO Analyzer Instruction Manual, 2006.

[8] Rosemount NOx Analyzer, Model 951C, Product Data Sheet, May, 2009.

[9] Tony R. Kuphaldt; "Lessons In Industrial Instrumentation, Version 1.12", September 20, 2010.ISBN (1009217397803).

[10] Partha S. Sarathi; "Combustion Handbook Principles and Practice", 1999. DOEIPC 191008-0374, Distribution Category UC-122.

[11] Weber, Roman; "Combustion Fundamentals with Elements of Chemical Thermodynamics", Clausthal-Zellerfeld, Papierflieger 2008, ISBN 9783-89720-921-3.

[12] Hjalti Kristinsson, "Boiler Control", Coden :Lutedx /(TEIE-5278)/1-89 (2011)

[13] Ken Heselton, "Boiler operator's handbook", ISBN 0-88173-434-9, 2004.

[14] Simatic HMI WinCC flexible 2008 Compact/Standard/Advanced, user's manual.

[15] Zhao li-ming and Zhang bing", Large Scale Motor Group Integrative Management and Control Network System Based on PLC-SCADA Under Complex Environment", Applied Mechanics and Materials Vol. 742 (2015) pp 698-707.

[16] S. Lishev, R. Popov, and A. Georgiev "Laboratory SCADA systems - the state of art and the challenges". Balkan journal of electrical \& computer engineering, ISSN 2147-284X, Vol.3, 2015.

\section{BIOGRAPHIES}

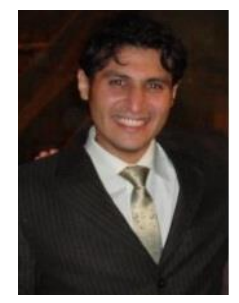

AHMED DARWISH Alexandria, in 1987. He received the B.S. in electronics and communication engineering from Arab Academy for engineering and technology, in 2010. He was I\&C engineer since 2011, His research interests include high-pressure boilers and highaccuracy instruments and its applications.

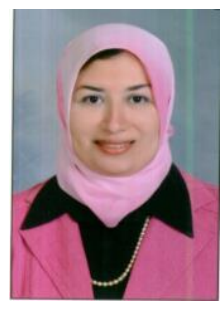

IMAN MORSI Morsi was born in 1969 at Alexandria. B.Sc. in Electrical Engineering (Electronics and Communications) from Alexandria University,Egypt,1991 .M.Sc. in Electrical Engineering (Electronics and Communications) "An Integrated Energy Management System for Intelligent Buildings" from the Faculty of Engineering, Alexandria University, Egypt,1969. PhD in Electrical Engineering (Electronics and Communications),"Photovoltaic Systems Management Using Artificial Intelligence Techniques" from the Faculty of Engineering, Alexandria University, Egypt, 2002.

Currently: Vice-Dean of Training Affairs and Community Service of Arab Academy for Science and Technology and Maritime Transport (AASTMT), Abo-Qir Campus, Alexandria. Professor in Electronics and Communications Department in Faculty of Engineering (AASTMT). Field of interests are: Sensors fabrication and applications. Application using microcontroller and PLC. Data fusion system using artificial intelligence techniques. IEEE Senior member in measurements society. I got Marquis' Who's Who Award for outstanding achievement in my own field and Socity,2007. I contributed in many community services and charities. 


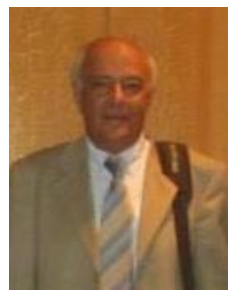

Amr M. O. El ZAWAWI Born on 1950 in Alexandria, Egypt. He obtained his BSc and MSc in Electrical Engineering from the University of Alexandria on 1972 and 1976 receptively. He obtained the DEA and PhD degree from the INPG, France on 1977and 1980 respectively. His fields of interest are Electric Machines and Power Electronics. He served as a teaching assistant, assistant lecturer, lecturer and associate professor in the department of Electrical Alexandria Engineering, Faculty of Engineering, the University of 